DOI: https://doi.org/10.15688/jvolsu3.2019.2.4

UDC 338.439.02:43.021

Submitted: 19.03.2019

LBC 65.9(2)32

Accepted: 28.03.2019

\title{
THE RATING ASSESSMENT OF FOOD SECURITY OF THE SOUTHERN FEDERAL DISTRICT REGIONS ${ }^{1}$
}

\author{
Elena N. Antamoshkina
}

Volgograd State Agrarian University, Volgograd, Russian Federation

\begin{abstract}
The article proposes the methodological tool and comprehensive indicator for assessing the food security of the regions. The index of food security is determined on the basis of the systematic groups of indicators. In the distribution of food products, the following indicators are analyzed: the indexes of food prices, the magnitude of the change in real incomes of the population, the population with incomes below the subsistence minimum. Among the indicators in the distribution of food products the volume of food consumption in accordance with rational consumption rates, the share of food expenditure in the structure of household consumption expenditures are considered. In the field of production the indexes of production of various types of agricultural products in the region are considered.

The ranking of the Southern Federal District (SFD) regions by selected groups of indicators made it possible to determine the leaders in food security among the regions. In 2017, Krasnodar Krai, the Republic of Adygea and Rostov Region were among these regions. On the basis of the analysis performed, the authors established risks and threats in food supply of the SFD regions: imbalance of the consumer ration; decrease in real incomes and purchasing power of population; a high proportion of the population with incomes below the subsistence minimum in the region. The practical significance of the proposed approach lies in the possibility of justifying the choice of priority measures to optimize agrarian policy, taking into account the need to maintain an acceptable level of food provision in the regions of Russia.

Key words: food security, food security index, region, agricultural products, rational food consumption rates.

Citation. Antamoshkina E.N. The Rating Assessment of Food Security of the Southern Federal District Regions. Vestnik Volgogradskogo gosudarstvennogo universiteta. Seriya 3, Ekonomika. Ekologiya [Science Journal of Volgograd State University. Global Economic System], 2019, vol. 21, no. 2, pp. 44-54. (in Russian). DOI: https://doi.org/10.15688/jvolsu3.2019.2.4
\end{abstract}

УДК 338.439.02:43.021

Дата поступления статьи: 19.03.2019

ББК $65.9(2) 32$

Дата принятия статьи: 28.03.2019

\section{సे РЕЙТИНГОВАЯ ОЦЕНКА ПРОДОВОЛЬСТВЕННОЙ ОБЕСПЕЧЕННОСТИ РЕГИОНОВ ЮФО ${ }^{1}$}

\section{Елена Николаевна Антамошкина}

Волгоградский государственный аграрный университет, г. Волгоград, Российская Федерация

Аннотация. В статье предлагается методический инструментарий и комплексный показатель оценки продовольственной обеспеченности регионов. Индекс продовольственной обеспеченности определяется на основе систематизированных групп показателей. В сфере распределения продовольственной продукции 
анализируются индексы цен на продовольствие, величина изменения реальных денежных доходов населения, численность населения с доходами ниже прожиточного минимума. В числе показателей в сфере распределения рассматриваются объемы потребления продовольствия в сравнении с рациональными нормами и доля расходов на питание, в сфере производства - индексы выпуска различных видов сельскохозяйственной продукции в регионе.

Ранжирование регионов ЮФО по выбранным группам показателей позволило определить регионы лидеры по продовольственной обеспеченности, в 2017 г. к числу таких регионов относились Краснодарский край, Республика Адыгея и Ростовская область. На основе проведенного анализа установлены риски и угрозы в продовольственном обеспечении регионов ЮФО: несбалансированность потребительского рациона; снижение реальных доходов и покупательной способности населения; высокий удельный вес населения с доходами ниже прожиточного минимума. Практическая значимость предлагаемого подхода заключается в возможности обоснования выбора приоритетных мер оптимизации аграрной политики с учетом необходимости поддержания приемлемого уровня продовольственной обеспеченности регионов России.

Ключевые слова: продовольственное обеспечение, индекс продовольственной обеспеченности, регион, сельскохозяйственная продукция, рациональные нормы потребления продовольствия.

Цитирование. Антамошкина Е. Н. Рейтинговая оценка продовольственной обеспеченности регионов ЮФО // Вестник Волгоградского государственного университета. Серия 3, Экономика. Экология. - 2019. T. 21, № 2. -C. 44-54. - DOI: https://doi.org/10.15688/jvolsu3.2019.2.4

\section{Введение}

В экономике практически каждой страны мира аграрный сектор занимает особое место, поскольку от его функционирования зависит степень удовлетворения потребностей населения в продовольствии, уровень продовольственной независимости и продовольственной безопасности страны. В Стратегии научно-технологического развития Российской Федерации отмечается, что обеспечение продовольственной безопасности и продовольственной независимости страны, достижение конкурентоспособности отечественной продукции на мировых рынках продовольствия относятся к числу больших вызовов, стоящих перед российской экономикой и обществом, в соответствии с которыми должны определяться приоритеты развития регионов страны [Стратегия ..., с. 7].

Продовольственное обеспечение населения и продовольственная безопасность государства должны иметь устойчивый характер, что позволит сформировать условия для планомерного замещения импортируемого продовольствия продукцией российских производителей и обеспечения населения качественной и безопасной продовольственной продукцией. В этой связи представляется теоретически и практически значимой проблема разработки методологии социально-экономического анализа региональных продовольственных рынков с целью осуществления мониторинга, оцен- ки состояния продовольственной обеспеченности и прогнозирования потребности в продовольствии для населения региона.

Отдельные аспекты продовольственной обеспеченности и продовольственной безопасности в контексте теории и практики устойчивого развития экономики регионов России представлены в работах А.И. Алтухова, В.И. Назаренко, А.В. Улезько, Т.М. Ярковой, П.М. Таранова [Алтухов, 2016; Назаренко, 2011; Улезько, 2014; Яркова, 2013; Таранов, 2016]. На развитие продовольственных рынков и организацию эффективной системы продовольственного обеспечения оказывают влияние экономические, социальные, экологические параметры аграрной экономики. В работах перечисленных авторов рассматриваются факторы и тенденции развития агропромышленного комплекса и аграрной политики России, анализируются региональные особенности развития продовольственных рынков, рассматривается влияние продовольственных рынков на продовольственную безопасность. В современных условиях особое внимание уделяется рассмотрению особенностей государственного регулирования агропродовольственных рынков и направлений совершенствования государственной агропродовольственной политики как инструмента обеспечения продовольственной безопасности.

В работах зарубежных исследователей продовольственное обеспечение государства определяется тремя факторами: имеющими- 
ся поставщиками продовольствия (предложение), доходами населения (спрос) и доступом населения к продовольственным поставкам. Анализ мер регулирования и поддержки агропродовольственного сектора экономики, характеристика организации системы продовольственного обеспечения, контроля безопасности и качества продовольственной продукции в странах Европы, США, Канаде представлены в работах Р. Капоне, Х. Билали, Ф. Дебса [Food System ..., 2014].

\section{Методика исследования}

Для оценки продовольственной обеспеченности предлагается использовать комплексный показатель - индекс продовольственной обеспеченности ( $I_{F P}-$ Food Provision Index), учитывающий показатели в сфере производства ( $P$ - production), распределения $(D-$ distribution) и потребления ( $C$ - consumption) продовольственной продукции:

$$
I_{F P}=f(P ; D ; C) .
$$

В отличие от существующих методик оценки, индекс продовольственной обеспеченности будет определяться в соответствии с рядом параметров. Так, в числе показателей, характеризующих сферу распределения продовольственной продукции, предлагается анализировать: индекс цен на продовольствие, величину изменения реальных денежных доходов населения региона, удельный вес населения с доходами ниже прожиточного минимума по региону. Среди показателей, характеризующих сферу потребления продовольственной продукции, следует учитывать долю расходов на питание в структуре потребительских расходов и объемы потребления продуктов питания в соответствии с рациональными нормами потребления [Антамошкина, 2015]. Показателями, которые необходимо учитывать при анализе сферы производства, являются индексы выпуска различных видов сельскохозяйственной продукции в регионе.

\section{Материалы и результаты исследования}

Регионы России, в которых активно развивается сельскохозяйственное производство, потенциально имеют преимущества в обеспечении проживающего на территории данных регионов населения продовольственной продукцией в сравнении с остальными регионами страны. ЮФО традиционно относится к регионам, специализирующимся на сельском хозяйстве, и занимает лидирующие позиции по производству зерна и зерновых культур, подсолнечника, овощей.

В 2017 г. в ЮФО наблюдался незначительный рост объемов производства сельскохозяйственной продукции, по сравнению с объемами выпуска 2016 г. - на уровне 3,1 \%. Большинство регионов ЮФО сохранили прежние объемы производства сельхозпродукции либо обеспечили несущественный прирост на уровне 1,5-3\%. Лидером по темпам роста объемов производства сельскохозяйственной продукции в 2017 г. стала Астраханская область, Республика Адыгея заняла лидирующие позиции по темпам роста производства животноводческой продукции. Совокупный объем сельскохозяйственной продукции по сравнению с объемами производства в 2016 г. возрос почти на $10 \%$. Единственный субъект региона, показатели производства сельскохозяйственной продукции в котором снизились в 2017 г., - это Республика Крым (см. табл. 1).

Данные по отраслям сельского хозяйства ЮФО показывают более высокие темпы роста в сфере растениеводства по сравнению с результатами, достигнутыми в производстве животноводческой продукции. В ЮФО в 2017 г. лидерами стали Астраханская область - 16,9 \% и Республика Калмыкия, где рост объемов растениеводческой продукции по итогам года составил 11,2 \%. Сократились объемы производства сельскохозяйственной продукции в Республиках Адыгея и Крым. Темпы роста объемов производства сельскохозяйственной продукции в отраслях животноводства в 2017 г. в ЮФО составили - 2,2 \%, лучшие показатели демонстрировали Республика Адыгея - 6,2 \% и Волгоградская область - 4,1 \%. Снизились объемы выпуска сельскохозяйственной продукции в сфере животноводства в Республиках Калмыкия и Крым, городе Севастополь.

В 2017 г. ЮФО традиционно занимает 1-е место в Российской Федерации по валовому сбору зерна в хозяйствах всех катего- 
Е.Н. Антамошкина. Рейтинговая оценка продовольственной обеспеченности регионов ЮФО

Таблища 1

Индексы производства сельскохозяйственной продукции в ЮФО, \%

\begin{tabular}{|l|c|r|r|r|r|r|}
\hline \multirow{2}{*}{ Регионы ЮФО } & \multicolumn{2}{|c|}{$\begin{array}{c}\text { Продукция } \\
\text { сельского хозяйства }\end{array}$} & \multicolumn{2}{c|}{$\begin{array}{c}\text { Продукция } \\
\text { растениеводства }\end{array}$} & \multicolumn{2}{c|}{$\begin{array}{c}\text { Продукция } \\
\text { животноводства }\end{array}$} \\
\cline { 2 - 7 } & 2016 г. & 2017 г. & 2016 г. & 2017 г. & 2016 г. & 2017 г. \\
\hline В среднем по РФ & 104,8 & 103,1 & 107,8 & 103,5 & 101,6 & 102,6 \\
\hline В среднем по ЮФО & 108,7 & 103,5 & 112,1 & 104,1 & 101,5 & 102,2 \\
\hline Республика Адыгея & 97,9 & 100,4 & 106,9 & 97,4 & 83,9 & 106,2 \\
\hline Республика Калмыкия & 102,2 & 101,1 & 142,8 & 111,2 & 95,2 & 98,9 \\
\hline Республика Крым & 100,3 & 96,4 & 104,5 & 94,1 & 95,0 & 99,9 \\
\hline Краснодарский край & 105,2 & 101,7 & 106,0 & 101,6 & 102,8 & 102,1 \\
\hline Астраханская область & 101,2 & 109,9 & 97,5 & 116,9 & 106,1 & 101,5 \\
\hline Волгоградская область & 114,5 & 102,6 & 119,4 & 102,1 & 103,1 & 104,1 \\
\hline Ростовская область & 115,7 & 107,6 & 121,6 & 109,6 & 103,6 & 103,0 \\
\hline г. Севастополь & 106,9 & 100,6 & 108,9 & 102,2 & 89,7 & 84,3 \\
\hline
\end{tabular}

Примечание. Составлено автором по: [Регионы России ..., 2018, с. 638].

рий. Краснодарский край обеспечил сбор 14 млн 80,8 тыс. тонн зерна - это лучший показатель по ЮФО и всем регионам России. Также среди регионов ЮФО в лидерах по сбору зерновых культур Ростовская область - 13 млн 459,6 тыс. тонн, это 2-е место по ЮФО и Российской Федерации в целом, Волгоградская область - 5 млн 651,4 тыс. тонн - 3-е место среди регионов ЮФО по сбору зерновых и 6-е место по всем регионам России [Регионы России ... , 2018, c. $683,711-717]$.

Еще одна сельскохозяйственная продукция, которая активно выращивается сельскохозяйственными производителями Юга России, - это подсолнечник. В 2017 г. сельхозпроизводители ЮФО смогли получить 3 млн 285,8 тыс. тонн семян подсолнечника регион занимает 2-е место в России после Приволжского федерального округа. Объемы производства в 2017 г. снизились на 3,1 \% по сравнению с уровнем сбора семян подсолнечника в 2016 г., в абсолютных единицах измерения производство сократилось на 106 тыс. тонн. Первое место среди регионов ЮФО и России в целом по сбору семян подсолнечника занимает Ростовская область - 1 млн 429,5 тыс. тонн, на 2-м месте по России и ЮФО - Краснодарский край, в 2017 г. было собрано более 1 млн 75 тыс. тонн подсолнечника. Волгоградская область обеспечила сбор 576 тыс. тонн подсолнечника, это 8-е место по регионам России и 3 -е место в ЮФО.
Объемы производства мяса и мясной продукции в ЮФО в 2017 г. возросли на 31,6 тыс. тонн, прирост составил $-3,16 \%$, peгион занимает 4-е место в России по количеству получаемой мясной продукции. В Краснодарском крае в 2017 г. было получено 373,1 тыс. тонн мясной продукции, по данному показателю регион занимает 1-е место в ЮФО и 3-е место по России. Сельхозпроизводители животноводческой продукции Ростовской области получили 268,7 тыс. тонн мясной продукции, это 11-е место по России и 2-е место среди регионов ЮФО. Большинство регионов ЮФО, за исключением Астраханской области и Республики Адыгея, в 2017 г. достигли увеличения объемов производства мясной продукции, в частности в Волгоградской области темпы роста составили $11,2 \%$.

Объемы производства молока в ЮФО в 2017 г. возросли по сравнению с уровнем 2016 г. на 34,1 тыс. тонн, в 2016 г. также был достигнут прирост данного показателя на 44,5 тыс. тонн. В 2017 г. производители Краснодарского края получили 1 млн 380 тыс. тонн молока, это превысило показатель предыдущего года на $1,8 \%$, в Ростовской области был получен 1 млн 91,1 тыс. тонн молока, что также выше показателей за 2016 г. на 1,8 тыс. тонн $(0,2 \%)$. В отдельных регионах ЮФО производство молока в 2017 г. сократилось, в частности в Республике Калмыкия - с 70,3 до 67,2 тыс. тонн, Республике Крым - с 212,2 до 209,7 тыс. тонн и городе Севастополь - с 3,2 до 2,8 тыс. тонн. 
Производство куриных яиц в ЮФО в 2017 г. возросло на 1,3 \%, было получено 5 353,8 млн штук яиц, по объемам производства данной категории продовольственной продукции ЮФО занимает 4-е место по России. Наибольшее количество данной продукции производится в Ростовской области 2 085,7 млн штук яиц, это 2-е место по России, и Краснодарском крае - 1 785,9 млн штук, 4-е место среди регионов России. Рекордные показатели по темпам прироста производства куриных яиц в 2017 г. среди регионов ЮФО продемонстрировала Республика Адыгея, темпы роста составили - 54,2\% в сравнении с 2016 г., в Адыгее было получено 105,3 млн штук куриных яиц.

Доступность продовольственной продукции для населения зависит от изменения уровня цен на продовольственные товары и реальных доходов потребителей. В 2017 г. в ЮФО индекс потребительских цен на продовольственные товары составил 100,3\%, максимального значения показатель достиг в Калмыкии - 103,3 \% [Регионы России ... , 2018, c. 1108]. В ряде регионов ЮФО - Ростовской области, Республиках Адыгея и Крым, городе Севастополь - было отмечено снижение индекса потребительских цен.

Возможности приобретения продовольственной продукции зависят не только от уровня цен, но от величины реальных денежных доходов населения. В 2017 г. среднедушевые денежные доходы в ЮФО незначительно возросли по сравнению с уровнем 2016 г. - на $2,4 \%$ - и составили 26 тыс. 928 рублей [Регионы России ..., 2018, с. 190]. В ЮФО максимальными денежные доходы были в Крас- нодарском крае - 33 тыс. 136 рублей, это 16е место среди регионов России, минимальными - в Калмыкии -14 730 рублей (84-е место) и Республике Крым - 20 тыс. 128 рублей (76-е место). В Волгоградской области размер среднедушевых денежных доходов составил - 21 тыс. 357 рублей, это 72-е место среди регионов России. Несмотря на прирост среднедушевых денежных доходов, по Волгоградской области в 2017 г. уровень денежных доходов остается ниже показателей 2015 г., аналогичная ситуация и в Астраханской области, где уровень среднедушевых денежных доходов в 2015 г. составлял чуть более 24 тыс. рублей, а в 2017 г. - 22 тыс. 519 рублей.

Среднедушевые денежные доходы не учитывают динамику изменения индекса потребительских цен, более объективную оценку покупательной способности населения позволяет получить анализ реальных денежных доходов в ЮФО (табл. 2). Реальные денежные доходы населения ЮФО в 2017 г. возросли только в 2 субъектах региона - Республике Крым - на 6,6 \% и Адыгее. Во всех остальных субъектах ЮФО, несмотря на увеличение номинальных денежных доходов в 2017 г., реальные денежные доходы населения сократились в среднем на $3 \%$

Среди негативных тенденций в ЮФО стоит отметить высокую степень поляризации населения по уровню доходов и высокий удельный вес численности населения с доходами ниже прожиточного минимума. В среднем по ЮФО численность населения с доходами ниже прожиточного минимума в 2017 г. составила $16,1 \%$ (см. рис. 1 ).

Реальные денежные доходы по субъектам ЮФО, в \% к предыдущему году

\begin{tabular}{|l|c|c|c|}
\hline \multicolumn{1}{|c|}{ Регионы ЮФО } & 2015 г. & 2016 г. & 2017 г. \\
\hline В среднем по РФ & 95,9 & 94,4 & 98,7 \\
\hline В среднем по ЮФО & 96,4 & 96,7 & 99,0 \\
\hline Республика Адыгея & 89,9 & 97,8 & 100,5 \\
\hline Республика Калмыкия & 98,9 & 94,2 & 97,9 \\
\hline Республика Крым & $\ldots$ & 103,6 & 106,6 \\
\hline Краснодарский край & 95,4 & 98,7 & 97,9 \\
\hline Астраханская область & 94,1 & 88,9 & 95,9 \\
\hline Волгоградская область & 97,6 & 88,9 & 98,8 \\
\hline Ростовская область & 98,7 & 95,7 & 98,7 \\
\hline г. Севастополь & $\ldots$ & 127,2 & 99,5 \\
\hline
\end{tabular}

Примечание. Составлено автором по: [Регионы России ..., 2018, с. 184]. 

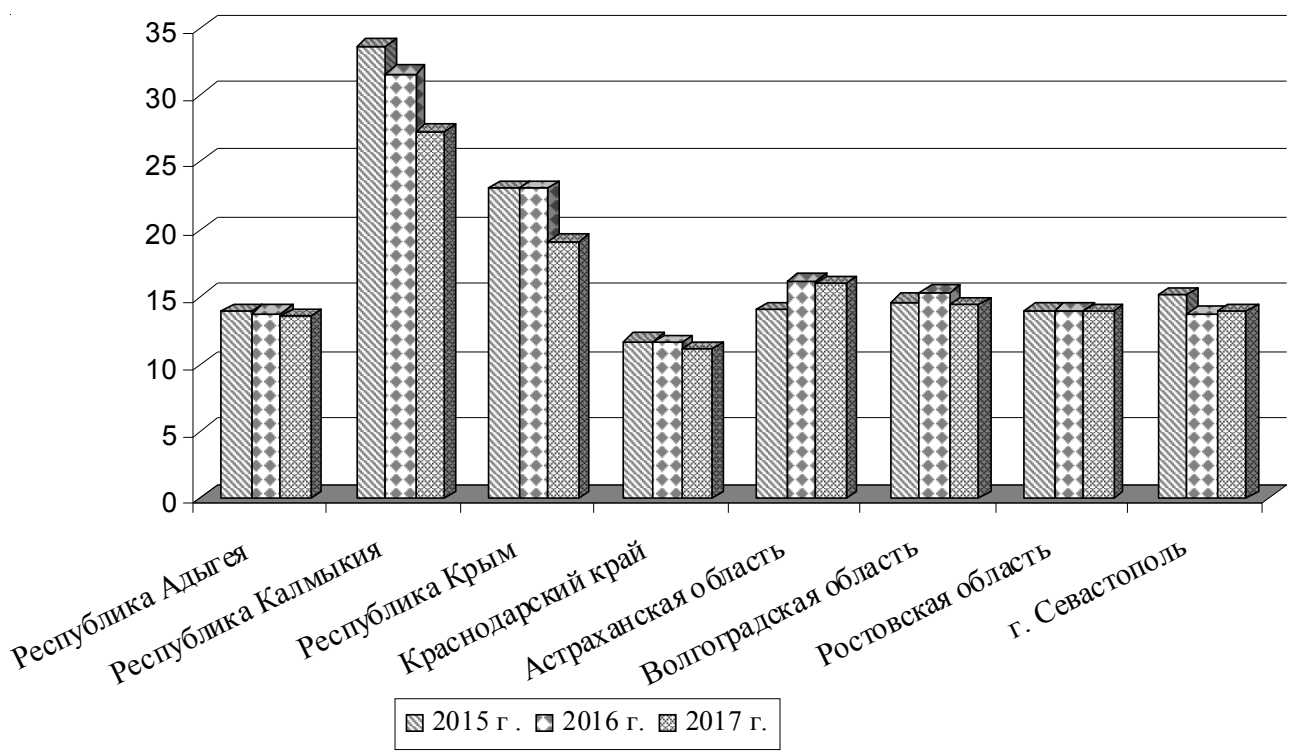

Рис. 1. Численность населения с доходами ниже прожиточного минимума в ЮФО, в \% от общей численности населения

Примечание. Составлено автором по: [Регионы России ..., 2018, с. 228].

Доля расходов на питание в структуре расходов домашних хозяйств ЮФО в 2017 г. составила $37,9 \%$, показатель по России в целом - ниже $34,3 \%$. В ряде регионов ЮФО складывается достаточно неблагоприятная ситуация с точки зрения структуры потребительских расходов. В Республике Крым и городе Севастополь около половины расходов домашних хозяйств составляют расходы на питание. Так, в Республике Крым в 2017 г. удельный вес расходов на питание в общей структуре потребительских расходов сократился на $5,4 \%$ в сравнении с уровнем расходов 2016 г. и составил - 46,2 \%, в городе Севастополь расходы на питание составили $52,7 \%$ от общего объема расходов потребителей [Регионы России ..., , 2018, с. 236]. Наиболее оптимальной, среди регионов ЮФО, в 2017 г. является структура потребительских расходов в Краснодарском крае, где 35,9 \% расходуется на приобретение продуктов питания, и Республике Калмыкия, где на покупку продуктов питания приходится $34,9 \%$ от общего объема расходов потребителей.

Анализ объемов потребления основных продуктов питания по субъектом ЮФО в 2017 г. позволяет сделать ряд выводов о структуре потребительского рациона населения и его недостаточной сбалансированности. Объемы потребления хлеба и хлебопро- дуктов (к данной категории относятся мука, крупы, рис, макаронные изделия и бобовые) по всем регионам ЮФО превышают средний объем потребления по России и рациональные нормы потребления хлебопродуктов. Так, в среднем по ЮФО объемы потребления хлебопродуктов на 23,9 \% превысили рациональную норму потребления. По отдельным регионам ЮФО уровень превышения был еще более значительным: в Краснодарском крае в 2017 г. фактический объем потребления хлебопродуктов превышал рациональный уровень на $37,55 \%$, в Астраханской области - на $34,3 \%$, в Калмыкии - на 28,1 \%. Наиболее приближенными к рациональным нормам были объемы потребления хлебопродуктов в Севастополе - 98 кг за год (см. табл. 3).

Традиционно хлебопродукты на продовольственном рынке являются самыми доступными по цене продуктами питания, и население, не имея возможности приобрести достаточное для потребления в соответствии с установленными рациональными нормами количество молочной продукции, рыбы, фруктов, компенсирует недостаток калорий в потребительном рационе за счет хлебопродуктов.

Объемы потребления мяса и мясопродуктов в 2017 г. в среднем по ЮФО на 2 кг превысили установленную рациональную норму (73 кг/год). При этом по субъектам ЮФО 
Потребление продуктов питания в ЮФО в 2017 г.

(в среднем на одного члена домашнего хозяйства в год, кг)

\begin{tabular}{|l|c|c|c|c|c|c|}
\hline \multicolumn{1}{|c|}{ Регионы ЮФО } & $\begin{array}{c}\text { Хлебные } \\
\text { продукты }\end{array}$ & $\begin{array}{c}\text { Мясные } \\
\text { продукты }\end{array}$ & $\begin{array}{c}\text { Молочные } \\
\text { продукты }\end{array}$ & Яйца, шт. & Сахар & $\begin{array}{c}\text { Маслорас- } \\
\text { тительное }\end{array}$ \\
\hline В среднем поРФ & 117 & 75 & 231 & 279 & 39 & 13,9 \\
\hline В среднем поЮФО & 119 & 75 & 216 & 306 & 42 & 14,6 \\
\hline Республика Адыгея & 117 & 68 & 205 & 253 & 47 & 11,2 \\
\hline Республика Калмыкия & 123 & 115 & 226 & 229 & 26 & 11,6 \\
\hline Республика Крым & 113 & 53 & 165 & 241 & 38 & 12,7 \\
\hline Краснодарский край & 132 & 83 & 224 & 328 & 50 & 17,4 \\
\hline Астраханская область & 129 & 80 & 198 & 239 & 42 & 11,4 \\
\hline Волгоградская область & 117 & 75 & 195 & 313 & 35 & 12,8 \\
\hline Ростовская область & 104 & 72 & 254 & 335 & 39 & 14,6 \\
\hline г. Севастополь & 98 & 61 & 138 & 249 & 27 & 10,9 \\
\hline $\begin{array}{l}\text { Рациональнье нормы } \\
\text { потребления }\end{array}$ & 96 & 73 & 325 & 260 & 24 & 12,0 \\
\hline
\end{tabular}

Примечание. Составлено автором по: [Регионы России ..., 2018, с. 248-252].

в 2017 г. ситуация с потреблением мяса (говядины, баранины, свинины, мяса птицы) была неоднородной. В отдельных регионах, в частности в Республиках Адыгея, Крым, городе Севастополь, Ростовской области, объемы потребления были ниже установленных рациональных норм.

Лидировала по объему потребления мяса Калмыкия - 115 кг в год, что на 57,5 \% превысило установленную рациональную норму. В пищевом рационе населения региона преимущественно преобладает мясо баранины. В приложении к рекомендациям по рациональным нормам потребления пищевых продуктов приводятся нормы потребления баранины 3 кг в год, говядины - 20 кг, мяса птицы (цыплята, куры, индейка, утки, гуси и др.) - 31 кг, свинины - 18 кг. С точки зрения структуры потребительского рациона, несмотря на значительное превышение в объемах потребления мяса и мясопродуктов населением Калмыкии, потребительский рацион можно считать несбалансированным. Объемы потребления мясопродуктов в 2017 г. незначительно превысили рациональную норму в Краснодарском крае - на 13,6 \%, Астраханской и Волгоградской областях на 9,5 и $2,7 \%$ соответственно.

Достаточно сложной на продовольственном рынке продолжает оставаться ситуация с потреблением молока и молочной продукции. При установленной рациональной норме потребления 325 кг в год объемы потребле- ния в среднем по ЮФО в 2017 г. составили 216 кг, это всего 66,5 \% от рекомендуемой рациональной нормы потребления (см. рис. 2). Объемы потребления молока и молочной продукции по ЮФО были ниже среднего объема потребления по России в целом на 15 кг в год. Среди регионов ЮФО минимальными объемы потребления молочной продукции в 2017 г. были в городе Севастополь - 138 кг, что составило менее половины от рациональной нормы потребления (всего 42,5 \%), Республике Крым - 165 кг (50,7 \% от нормы потребления), Волгоградской области - 195 кг (60 \%), Астраханской области - 198 кг (60,1%). Максимальное количество молочной продукции в 2017 г. среди жителей ЮФО потребляло население Ростовской области - 254 кг в год, но и здесь наблюдалось отклонение от рациональной нормы на 21,8 \%.

Фактический объем потребления яиц по ЮФО в 2017 г. составил в среднем 306 шт, по данному показателю регион превысил средний уровень потребления по России на 9,7 \%. В ряде регионов ЮФО объем потребления яиц превышал рациональную норму: в Краснодарском крае объем потребления составил 328 шт., что на 26,1 \% превысило рациональную норму, в Ростовской области - 335 шт., превышение составило 28,8 \%, в Волгоградской области - 313 шт., на 20,4 \% больше рациональной нормы потребления. Вместе с тем в остальных регионах ЮФО объем потребления яиц в 2017 г. был ниже установленных 
Е.Н. Антамошкина. Рейтинговая оценка продовольственной обеспеченности регионов ЮФО

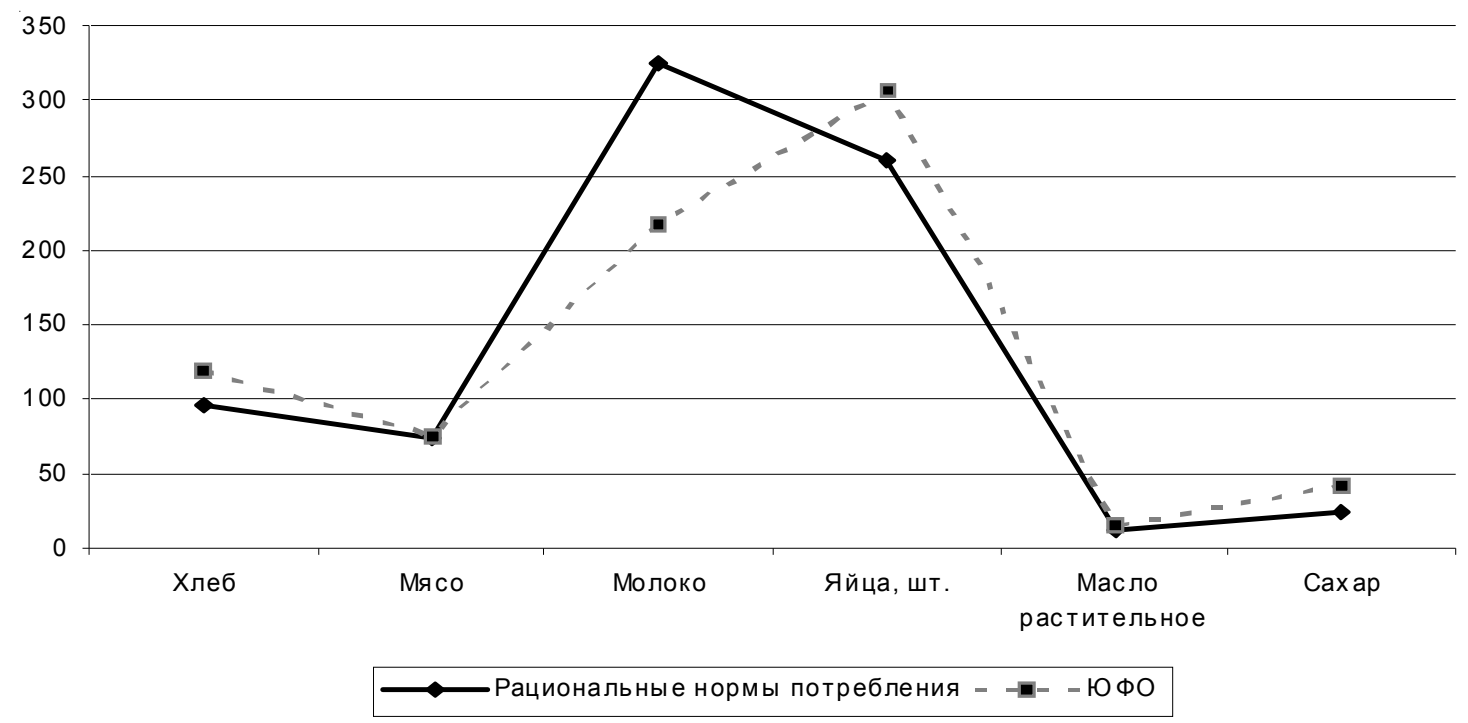

Рис. 2. Объемы потребления продуктов питания в ЮФО в 2017 г.

в сравнении с рациональными нормами потребления

Примечание. Составлено автором по: [Регионы России ..., 2018, с. 248-252].

норм потребления по данной категории продовольствия. В Республике Калмыкия объем потребления составил - 229 шт., что на $12 \%$ ниже рациональной нормы, в Астраханской области - 239 шт., отклонение от рациональной нормы на 8 \%, в Республике Адыгея и городе Севастополь объемы потребления яиц были незначительно ниже рациональных норм потребления.

Установленную рациональную норму потребления сахара в 24 кг в год население ЮФО в 2017 г. превысило практически в 2 раза, средний объем потребления составил 42 кг, что превышало и средний показатель по России - 39 кг. Примерно соответствовали рациональным нормам объемы потребления сахара в Калмыкии - 26 кг и городе Севастополь - 27 кг. По остальным регионам ЮФО в 2017 году объемы потребления сахара превышали установленные рациональные нормы. В Республике Адыгея объем потребления сахара превысил рациональную норму в 1,95 раза, в Республике Крым - в 1,6 раза, в Краснодарском крае - в 2,1 раза, Астраханской области - в 1,75 раза, Волгоградской области - 1,4 раза. Столь значительное превышение объемов потребления сахара по сравнению с установленными рациональными нормами также свидетельствует о несбалансированности продовольственного рациона населения ЮФО.
Объем потребления растительного масла в 2017 г. населением ЮФО составил 14,6 кг, что незначительно превысило установленный рациональный уровень потребления - 12 кг. В отдельных регионах ЮФО объемы потребления масла растительного были на уровне рациональных норм: Волгоградская область 12,8 кг, Крым - 12,7 кг, - либо незначительно превышали установленную норму, например в Ростовской области - 14,6 кг. В ряде субъектов ЮФО, в частности Республике Адыгея, Калмыкии, Астраханской области, объемы потребления масла были незначительно ниже установленных показателей рационального потребления: в Адыгее - на 6,7 \%, в Калмыкии - на 3,3 \%, Астраханской области - на $5 \%$. В Краснодарском крае наблюдалось превышение фактических объемов потребления над установленными рациональными нормами на $45 \%$, уровень потребления был равен 17,4 кг. С точки зрения распределения сельскохозяйственной продукции на продовольственном рынке данную ситуацию можно объяснить тем, что одним из направлений специализации Краснодарского края в сельскохозяйственном производстве является выращивание семян подсолнечника и других масличных культур - сои, рапса, клещевины.

Для проведения рейтинговой оценки продовольственной обеспеченности ЮФО необходимо систематизировать показатели в сфе- 
ре производства $(P)$, распределения $(D)$ и потребления $(C)$ продовольственной продукции по регионам Южного федерального округа. Данные представим в таблице 4.

Процедура ранжирования регионов ЮФО по выбранным группам показателей в сфере продовольственной обеспеченности проводилась в несколько этапов. Вначале необходимо определить значение изменения анализируемых показателей, в частности при анализе объемов потребления продуктов питания $\left(\mathrm{c}_{2}\right)$ учитывается отклонение фактических объемов потребления различных видов продовольствия от рациональных норм. При ранжировании регионов по выбранным показателям в сфере производства, распределения и потребления продовольственной продукции учитывалось, что для ряда показателей $\left(\mathrm{p}_{1}-\right.$ индексы производства сельскохозяйственной продукции, $\mathrm{d}_{2}$ - реальные денежные доходы населения) установлена прямая зависимость между изменением показателя и присваиваемым рангом по рейтингу регионов. Между изменением показателей $\left(\mathrm{d}_{1}-\right.$ индексы цен на продовольственную продукцию, $\mathrm{d}_{3}$ - численность населения с доходами ниже прожиточного минимума, $\mathrm{c}_{1}$ - доля расходов на питание в структуре потребительских расходов населения региона) и присваиваемым рангом установлена обратная зависимость, то есть чем ниже значение показателя, тем более высокий рейтинг получает регион по данному показателю (табл. 5).

В соответствии с присвоенными значениями ранга регионов по показателям в сфере продовольственного обеспечения определен совокупный рейтинг по показателям продовольственной обеспеченности $\left(I_{F P}\right)$. В том

Таблица 4

Показатели продовольственной обеспеченности по субъектам ЮФО в 2017 г., \%

\begin{tabular}{|l|r|r|r|r|r|r|}
\hline \multirow{2}{*}{ Регионы ЮФО } & \multicolumn{6}{|c|}{ Значения показателей*, $I_{F P}=f(P ; D ; C)$} \\
\cline { 2 - 7 } & $P$ & \multicolumn{1}{c|}{$D$} & \multicolumn{3}{c|}{$C$} \\
\cline { 2 - 7 } & \multicolumn{1}{|c|}{$\mathrm{p}_{1}$} & \multicolumn{1}{c|}{$\mathrm{d}_{1}$} & \multicolumn{1}{c|}{$\mathrm{d}_{2}$} & \multicolumn{1}{c|}{$\mathrm{d}_{3}$} & $\mathrm{c}_{1}$ & $\mathrm{c}_{2}$ \\
\hline Республика Адыгея & 100,4 & 99,5 & 100,5 & 13,5 & 37,3 & 110,7 \\
\hline Республика Калмыкия & 101,1 & 103,3 & 97,9 & 27,3 & 34,9 & 112,1, \\
\hline Республика Крым & 96,4 & 98,1 & 106,6 & 19,1 & 46,2 & 99,6 \\
\hline Краснодарский край & 101,7 & 100,4 & 97,9 & 11,1 & 35,9 & 121,6 \\
\hline Астраханская область & 109,9 & 100,2 & 95,9 & 16,0 & 38,1 & 111,3 \\
\hline Волгоградская область & 102,6 & 101,7 & 98,8 & 14,4 & 35,6 & 109,6 \\
\hline Ростовская область & 107,6 & 99,6 & 98,7 & 13,9 & 37,3 & 98,3 \\
\hline г. Севастополь & 100,6 & 99,7 & 99,5 & 13,9 & 52,7 & 95,4 \\
\hline
\end{tabular}

Примечания. Составлено автором. ${ }^{*} \mathrm{p}_{1}-$ индексы производства сельскохозяйственной продукции, \%; $\mathrm{d}_{1}$ - индексы цен на продовольственную продукцию, $\% ; \mathrm{d}_{2}$ - реальные денежные доходы населения в \% к предыдущему году; $\mathrm{d}_{3}-$ численность населения с доходами ниже прожиточного минимума, \%; $\mathrm{c}_{1}-$ доля расходов на питание в структуре потребительских расходов, \%; с - - объемы потребления продуктов питания, в \% от рациональной нормы потребления.

Таблииа 5

Ранжирование регионов ЮФО по уровню продовольственной обеспеченности в 2017 г.

\begin{tabular}{|c|c|c|c|c|c|c|c|c|c|}
\hline \multirow{3}{*}{ Регионы ЮФО } & \multicolumn{6}{|c|}{ Рейтинг по показателям } & \multirow{3}{*}{$I_{F P}$} & \multirow{3}{*}{$\begin{array}{c}\text { Среднее значе- } \\
\text { ние рейтинга }\end{array}$} & \multirow{3}{*}{ Ранг } \\
\hline & $P$ & \multicolumn{3}{|c|}{$D$} & \multicolumn{2}{|c|}{$C$} & & & \\
\hline & $\mathrm{p}_{1}$ & $\mathrm{~d}_{1}$ & $\mathrm{~d}_{2}$ & $\mathrm{~d}_{3}$ & $\mathrm{c}_{1}$ & $\mathrm{c}_{2}$ & & & \\
\hline Республика Адыгея & 5 & 2 & 2 & 2,0 & 4,5 & 5,0 & 20,5 & 3,40 & 1 \\
\hline Республика Калмыкия & 6 & 7 & 6 & 8,0 & 1,0 & 3,0 & 31,0 & 5,10 & 7 \\
\hline Республика Крым & 8 & 1 & 1 & 7,0 & 7,0 & 1,2 & 25,5 & 4,25 & 4 \\
\hline Краснодарский край & 4 & 6 & 7 & 1,0 & 3,0 & 1,2 & 22,5 & 3,75 & 2 \\
\hline Астраханская область & 1 & 5 & 8 & 6,0 & 6,0 & 4,0 & 30,0 & 5,00 & 6 \\
\hline Волгоградская область & 3 & 7 & 4 & 5,0 & 2,0 & 6,0 & 27,0 & 4,50 & 5 \\
\hline Ростовская область & 2 & 3 & 5 & 3,4 & 4,5 & 7,0 & 25,0 & 4,10 & 3 \\
\hline г. Севастополь & 7 & 4 & 3 & 3,4 & 8,0 & 8,0 & 33,5 & 5,60 & 8 \\
\hline
\end{tabular}

Примечание. Рассчитано автором. 
случае, если по результатам рейтинга несколько регионов получали одинаковую оценку, в расчет бралось среднее значение по рейтингу для каждого из таких регионов. Для определения ранга регионов ЮФО по продовольственной обеспеченности были рассчитаны средние значения рейтинга для каждого региона.

\section{Заключение}

По результатам проведенного анализа и ранжирования регионов ЮФО по уровню продовольственной обеспеченности в 2017 г. оптимальные показатели демонстрировали Республика Адыгея, Краснодарский край, Ростовская область. В сфере сельского хозяйства ЮФО по целому ряду видов сельскохозяйственной продукции наблюдалась положительная динамика: возросли объемы производства зерна, молока и молочной продукции, а также мясной продукции. По достигнутым темпам роста лидировали Республика Адыгея и Астраханская область. Индекс потребительских цен в ЮФО в 2017 г. находился на минимальном уровне за три последних года. Показатели были ниже среднего уровня индекса потребительских цен по России, а в ряде регионов ЮФО - Республиках Адыгея, Крым, Ростовской области, городе Севастополь - была зафиксирована отрицательная динамика показателя.

Вместе с тем по целому ряду анализируемых показателей присутствуют риски и угрозы в продовольственном обеспечении населения регионов ЮФО. В большинстве регионов ЮФО в 2017 г. снизились реальные денежные доходы, за исключением Республик Адыгея и Крым. Аналогичная ситуация прослеживалась и в 2015-2016 гг., по ЮФО и большинству регионов, входящих в состав федерального округа, реальные денежные доходы населения сократились. Это отражается на покупательной способности населения и структуре потребительских расходов, когда значительную часть своего бюджета, в среднем 35-45 \%, потребители вынуждены расходовать на приобретение продуктов питания. Особенно неблагоприятной в 2017 г. была ситуация в Республике Крым и городе Севастополь, где 46,2 и $52,7 \%$ в структуре расхо- дов потребителей приходилось на покупку продуктов питания.

В ряде регионов ЮФО - Республиках Калмыкия и Крым - высокий удельный вес численности населения с доходами ниже прожиточного минимума - 27,3 и $19,1 \%$ соответственно. Показатели значительно превышают средний уровень по России и в целом говорят о невозможности приобретения данной категорией населения продуктов питания даже на минимально необходимом уровне. Потребительский рацион населения ЮФО несбалансирован: ряд категорий продовольственной продукции - хлеб и хлебопродукты, сахар, растительное масло, яйца - потребляются в объемах, во много превышающих рациональные нормы потребления. Объемы потребления молока и молочной продукции ниже установленных рациональных норм.

Предлагаемый подход к оценке продовольственной обеспеченности регионов позволяет на основе статистических данных получить объективную оценку для выбора приоритетных мер по оптимизации аграрной политики с учетом необходимости поддержания приемлемого уровня продовольственной обеспеченности регионов России.

\section{ПРИМЕЧАНИЕ}

${ }^{1}$ Исследование выполнено при финансовой поддержке РФФИ и Администрации Волгоградской области в рамках научного проекта № 18-410340011 p_a.

The study was supported by the Russian Foundation for Basic Research (RFBR) and the Volgograd Region Administration in the framework of no. 18-410-340011 p_a scientific project.

\section{СПИСОК ЛИТЕРАТУРЫ}

Алтухов, А. И. Регион в системе обеспечения продовольственной безопасности страны: методологический аспект / А. И. Алтухов // Агропродовольственная политика России. - 2016. № 5. - C. 5-12.

Антамошкина, Е. Н. Методика анализа продовольственной безопасности на макрорегиональном уровне / Е. Н. Антамошкина // Национальные интересы: приоритеты и безопасность. - 2015. - № 24 (309). - С. 25-34. 
Назаренко, В. И. Продовольственная безопасность (в мире и в России) / В. И. Назаренко. - М. : Памятники исторической мысли, 2011.-286 c.

Регионы России. Социально-экономические показатели, 2018: Стат. сб. - М. : Росстат, 2018. -1162 c.

Стратегия научно-технологического развития Российской Федерации. - Электрон. текстовые дан. Режим доступа: http://www.kremlin.ru/acts/bank/ 41449 (дата обращения: 20.02.2019). - Загл. с экрана.

Таранов, П. М. Государственное регулирование агропродовольственных рынков в условиях геоэкономической напряженности / П. М. Таранов // Вестник АПК Ставрополья. - 2016. № $3(22 / 1)$. - С. 135-141.

Улезько, А. В. Рынок продовольственных ресурсов в системе обеспечения продовольственной безопасности Дальнего Востока : монография / А. Е. Улезько. - Воронеж : ФГБОУ ВПО Воронежский ГАУ, 2014. $291 \mathrm{c}$.

Яркова, Т. М. Определение государственной поддержки генерирования продовольственных запасов региона в формате ВТО / Т. М. Яркова // Экономика региона. -2013. - № 4 (36). - С. 157-166.

Food System Sustainability and Food Security: Connecting the Dots / R. Capone, H. El. Bilali, P. Debs, G. Cardone, N. Driouech // Journal of Food Security. -2014. - Vol. 2, № 1. - P. 13-22.

\section{REFERENCES}

Altuhov A.I. Region v sisteme obespechenija prodovol'stvennoj bezopasnosti strany: metodologicheskij aspekt [Region in the system of ensuring food security of the country: a methodological aspect]. Agroprodovol'stvennaja politika Rossii [Agrofood policy of Russia], 2016, no. 5, pp. 5-12.

Antamoshkina E.N. Metodika analiza prodovol'stvennoj bezopasnosti na makro regional'nom urovne
[Analysis of food security at the macro-regional level]. Nacional'nye interesy: prioritety $i$ bezopasnost' [National interests: priorities and security], 2015, no. 24 (309), pp. 25-34.

Nazarenko V.I. Prodovol'stvennaja bezopasnost' (v mire $i v$ Rossii) [Food security (in the world and in Russia)]. Moscow, Monuments of historical thought, 2011.286 p.

Regiony Rossii. Social'no-jekonomicheskie pokazateli, 2018: stat. sbornik [Regions of Russia. Socio-economic indicators, 2018]. Moscow, Rosstat Publ, 2018. 1162 p.

Strategiya nauchno-tehnologicheskogo razvitija Rossijskoj Federacii [The strategy of scientific and technological development of the Russian Federation]. URL: http://www.kremlin.ru/acts/ bank/41449 (accessed 20 February 2019).

Taranov P.M. Gosudarstvennoe regulirovanie agroprodovol'stvennyh rynkov v uslovijah geojekonomicheskoj naprjazhennosti [State regulation of agrifood markets in the context of geoeconomic tensions]. Vestnik APK Stavropol'ja [Bulletin of the agro-industrial complex of Stavropol], 2016, no. 3(22/1), pp. 135-141.

Ulez'ko A.V. Rynok prodovol'stvennyh resursov $v$ sisteme obespechenija prodovol'stvennoj bezopasnosti Dal'nego Vostoka: monografija [The market of food resources in the system of ensuring food security of the Far East]. Voronezh, Voronezhskij GAU, 2014. 291 p.

Jarkova T.M. Opredelenie gosudarstvennoj podderzhki generirovanija prodovol'stvennyh zapasov regiona $\mathrm{v}$ formate $\mathrm{VTO}$ [Determination of state support for the generation of food stocks in the region in the format of the WTO]. Jekonomika regiona [Economy of the region], 2013, no. 4 (36), pp. 157-166.

Capone R., Bilali H.El., Debs P., Cardone G., Driouech N. Food System Sustainability and Food Security: Connecting the Dots. Journal of Food Security, 2014, vol. 2, no. 1, pp. 13-22.

\section{Information about the Author}

Elena N. Antamoshkina, Candidate of Sciences (Economics), Associate Professor, Department of Social and Cultural Service, Volgograd State Agrarian University, Prosp. Universitetsky, 26, 400002 Volgograd, Russian Federation, antamoshkina@mail.ru, https://orcid.org/0000-0002-1306-616X

\section{Информация об авторе}

Елена Николаевна Антамошкина, кандидат экономических наук, доцент кафедры социально-культурного сервиса, Волгоградский государственный аграрный университет, просп. Университетский, 26, 400002 г. Волгоград, Российская Федерация, antamoshkina@mail.ru, https://orcid.org/0000-0002-1306-616X 